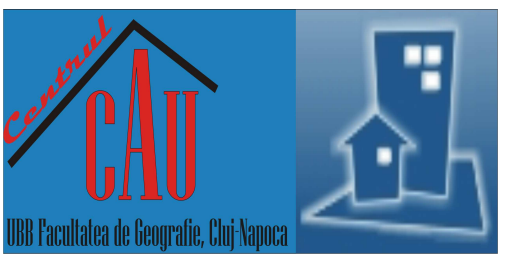

\title{
A Sustainable Approach for Site Selection of Underground Hydrogen Storage Facilities Using Fuzzy-Delphi Methodology
}

\author{
Behrouz NEMATI' ${ }^{1}$ Mahsa MAPAR ${ }^{2}$, Peyman DAVARAZAR 3 , Sara ZANDI ${ }^{1}$, Mahsa \\ DAVARAZAR', Dina JAHANIANFARD ${ }^{* * *}$, Mehdi MOHAMMADI \\ ${ }^{*}$ Corresponding author \\ ${ }^{* * *}$ The author has the same share as the first author \\ ${ }^{1}$ University of Aveiro, Department of Environment and Planning, Aveiro, PORTUGAL \\ ${ }^{2}$ NOVA University Lisbon, School of Science and Technology, Department of Environmental Sciences and Engineering, CENSE, \\ Centre for Environmental and Sustainability Research, Caparica, PORTUGAL \\ 3 University of Aveiro, Department of Civil Engineering, Aveiro, PORTUGAL
}

E-mail:dinaj@ua.pt

DOI: $10.24193 /$ JSSPSI.2020.6.02

https://doi.org/10.24193/JSSPSI.2020.6.02

K e y w o r d s: hydrogen, underground storage, Fuzzy-Delphi methodology, renewable energy, site selection

\begin{abstract}
A B S T RA C T
One of the consequences of rapid global population growth is the increase in the energy demand. Currently, the main source of energy for various applications is fossil fuels, which are not renewable and their utilization at large scales have caused a number of environmental issues such as global warming. Hydrogen is one of the main renewable energy sources; however, its utilization has not yet been sufficiently commercialized due to some existing technical issues. For large-scale underground Hydrogen storage facilities, selecting the most suitable set-up location is accounted to be a crucial factor in order to use Hydrogen as a promising and environmentally friendly energy carrier. This study aims to develop an expert judgment approach for the prioritization of criteria involving site selection of large-scale Hydrogen storage facilities to support development of modern cities and industries. In this regard, Fuzzy-Delphi methodology was used to prioritize the criteria and sub-criteria, which seemed to be most relevant for the underground Hydrogen storage site selection process. A comprehensive screening was performed in the literature and eighteen criteria from technical, economic, health, safety and environment (HST) and social points of view were extracted. A professional questionnaire was designed for the criteria prioritization and SPSS 25.0 was employed to analyse the achieved results. According to the gained results, the most important sub-criteria were identified as legal restrictions, reservoir permeability and porosity, and regional risks. Also, the findings demonstrated that HSE and technical issues of sustainability for the site selection of $\mathrm{H}_{2}$ underground storage were more underscored in comparison to economic and social criteria. It is concluded that more in-depth studies are still needed to cover more aspects of sustainability regarding site selection for underground gas storages with special focus on social dimensions.
\end{abstract}

\section{INTRODUCTION}

According to the roadmap designed by the European Commission (2011), it has become mandatory for the European countries to promote renewable sources to provide their required energy by 2050
(Babonneau et al., 2016; Read et al., 2016). The main goal for this switch from fossil fuels to renewable energy sources, is to mitigate the release of $\mathrm{CO}_{2}$ into the atmosphere (Crotogino et al., 2010; Türkseven Doğrusoy and Serin, 2015; Reuß et al., 2017). However, the utilization of the renewable energy sources (RES) is 
still limited due to the existing barriers. For instance, RES require a huge amount of investments and specific conditions to operate. Even thereafter, the preparation of the ideal conditions, RES will not be able to achieve the same efficiency level in comparison with fossil fuels (Kádár, 2014; Rocco, 2016). In addition, the produced electricity from RES must be utilized right away. This is mainly due to the existing technical limitations of RES storage techniques. Application of batteries for the RES storage has been proposed over the past decades as an effective method to deal with this problem. However, batteries are not widely applicable due to existing economic barriers.

To be able to provide the required energy for various applications such as energy supply for future smart cities, Hydrogen $\left(\mathrm{H}_{2}\right)$ storage has been accounted as a promising alternative. $\mathrm{H}_{2}$ can be produced either by electricity or water electrolysis (Roumpedakis et al., 2018). Furthermore, when required, $\mathrm{H}_{2}$ can again be converted to electricity at the high rate of efficiency with a minimum energy loss (European Commission, 2011; Hopper, 2017; Pesonen and Alakunnas, 2017; Sherif et al., 2003). Hence, Hydrogen energy can be considered satisfactory for the EU roadmap for clean and renewable energies development.

$\mathrm{H}_{2}$ can be stored in gas or liquid forms. The storage of $\mathrm{H}_{2}$ in liquid form necessitates some particular conditions such as low temperature, which will increase the total energy supply costs (Reuß et al., 2017). In order to overcome such issues, on board $\mathrm{H}_{2}$ storage has been applied for the storage of gas-phase $\mathrm{H}_{2}$ as an affordable approach (HyUnder, 2014; Pritchard and Rattigan, 2010). Moreover, like all of the renewable energy sources, the utilization of $\mathrm{H}_{2}$ arises some limitations. One of the main obstacles on the way of $\mathrm{H}_{2}$ use is that a large amount of $\mathrm{H}_{2}$ is required to proceed with the energy production. $\mathrm{H}_{2}$ is accounted as one of the lightest elements and contains low amount of energy density (Larsen et al., 2004). For instance, in comparison to gasoline, to produce the same amount of energy, four times more volume of $\mathrm{H}_{2}$ is required (Tzimas et al., 2003). Generally, there are two types of onboard $\mathrm{H}_{2}$ storages, including surface storage and underground storage techniques. In order to store $\mathrm{H}_{2}$ above the ground, special tanks or reservoirs are required, which need high capital costs (Lord et al., 2014). Thus, underground $\mathrm{H}_{2}$ storages are considered to be more economic options to this end (Amos, 1998). Geological storages aquifers, rock and salt caverns (Tzimas et al., 2003), abandoned mines (Evans et al., 2006), and natural gas reservoir (Hagemann et al., 2018) are among the applicable underground Hydrogen storage facilities. However, there are some barriers for the application of underground Hydrogen storage facilities. For instance, $\mathrm{H}_{2}$ leakage is considered to be risky as the released $\mathrm{H}_{2}$ can react to other minerals surrounding the storage and produce hazardous contaminants (Lord et al., 2014). Hence, some specifications are required to select the most appropriate sites for the establishment of underground Hydrogen storage facilities. Such specifications can be categorized into specific criteria and sub-criteria. The relative importance of such criteria and sub-criteria can determine the relative suitability of the desired sites. In this regard, adoption of the most suitable approaches to analyse and weigh the mentioned criteria and subcriteria are vital. Fuzzy-Delphi methodology can be employed as a scientific-based analytical method for the prioritization of the important criteria in various fields of study (Jahanshahi et al., 2019; Kamali et al., 2015; Kamali et al., 2017).

The Fuzzy-Delphi methodology includes two separate and complementary procedures. Via the utilization of the Delphi methodology, the most suitable questionnaire is achieved. Furthermore, the affecting criteria in the questionnaire will be ranked by the application of the fuzzy set theory (Hsueh, 2015; Bouzon et al., 2016). The application of Fuzzy-Delphi methodology facilitates the prediction of the future outputs when the application of forecasting models is not possible (Aliev et al., 2004). Thus, in this study, the Fuzzy-Delphi approach was adopted to prioritize the main criteria and sub-criteria influencing the selection of the appropriate sites for setting up the underground Hydrogen storage facilities.

\section{THEORETICAL BACKGROUND}

Underground Hydrogen storage has been used since the beginning of the twenty-first century. However, very few studies with the sustainability perspectives have been performed to investigate the affecting criteria on the gas storage site selection process (Lewandowska-Śmierzchalska et al., 2018). Underground gas storage has numerous environmental, economic, and social benefits in addition to the energy supply security benefits (Deveci et al., 2015; Llamas and Cámara, 2014). In this regards, those few studies, considering the site selection of gas storage integrated with the sustainability objectives, have considered four main aspects of sustainability including: a). Technical (Lewandowska-Śmierzchalska et al., 2018; Tarkowski and Czapowski, 2018); b). Economic (LewandowskaŚmierzchalska et al., 2018; Tarkowski and Czapowski, 2018); c). Health, safety and environment (HSE) (Tarkowski and Czapowski, 2018), and d). Social criteria. According to Llamas and Cámara (2014), technical criteria can also be taken into account as one of the most significant aspects affecting the selection of the Hydrogen underground storage site, due to the high costs and risk involved in the investigation techniques. Also, Lewandowska-Śmierzchalska et al. (2018) 


\section{A Sustainable Approach for Site Selection of Underground Hydrogen Storage Facilities Using Fuzzy-Delphi Methodology \\ Journal Settlements and Spatial Planning, Special Issue, no. 6 (2020) 5-16 \\ Multi-Criteria Spatial Decision Support Systems for Sustainable Development}

indicated that technical dimensions should be considered with equal significance to environmental and economic criteria of the Hydrogen underground storage site selection.

Table 1. Identified criteria and sub-criteria for the site selection of the underground $\mathrm{H}_{2}$ storage facilities extracted from the literature review.

\begin{tabular}{|c|c|c|c|}
\hline Criteria & Sub-criteria & Definition/ Description & References \\
\hline \multirow{8}{*}{ Technical } & Geology & $\begin{array}{l}\text { Defined as the suitability of the structure and the } \\
\text { properties of the local rocks for constructing the } \\
\text { Hydrogen storage facility. }\end{array}$ & $\begin{array}{l}\text { Deveci, 2018; Simon et al., 2015; } \\
\text { Tarkowski and Czapowski, } 2018\end{array}$ \\
\hline & Depth & $\begin{array}{l}\text { Defined as the depth required for the Hydrogen } \\
\text { storage facility. }\end{array}$ & $\begin{array}{l}\text { Deveci, 2018; Lewandowska- } \\
\text { Śmierzchalska et al., } 2018\end{array}$ \\
\hline & Area & $\begin{array}{l}\text { As an indicator to calculate the Hydrogen storage } \\
\text { capacity, required or available in the geological } \\
\text { field. }\end{array}$ & $\begin{array}{l}\text { Deveci et al., 2015; Hsu et al., 2012; } \\
\text { Lewandowska-Śmierzchalska et al., } \\
2018\end{array}$ \\
\hline & Thickness & $\begin{array}{l}\text { Defined as the thickness of the reservoir required } \\
\text { for Hydrogen storage. }\end{array}$ & $\begin{array}{l}\text { Deveci, 2018; Deveci et al., 2015; Hsu } \\
\text { et al., 2012; Lewandowska- } \\
\text { Śmierzchalska et al., } 2018 \\
\end{array}$ \\
\hline & $\begin{array}{l}\text { Caprock } \\
\text { thickness }\end{array}$ & $\begin{array}{l}\text { Defined as the necessity of having caprocks with } \\
\text { sufficient thickness for the safe storage of } \\
\text { Hydrogen. }\end{array}$ & $\begin{array}{l}\text { Hsu et al., 2012; Chadwick et al., } \\
\text { 2008; Llamas and Cámara, 2014; } \\
\text { Ramírez et al., 2010; Sainz-Garcia et } \\
\text { al., } 2017\end{array}$ \\
\hline & $\begin{array}{l}\text { Caprock } \\
\text { permeability }\end{array}$ & $\begin{array}{l}\text { Defined as the sealing properties capacity of a } \\
\text { caprock, which enables successful sealing in the } \\
\text { reservoirs. }\end{array}$ & $\begin{array}{l}\text { Hsu et al., 2012; Chadwick et al., } \\
\text { 2008; Llamas and Cámara, 2014; } \\
\text { Ramírez et al., 2010; Sainz-Garcia et } \\
\text { al., } 2017\end{array}$ \\
\hline & $\begin{array}{l}\text { Reservoir } \\
\text { permeability } \\
\text { and porosity }\end{array}$ & $\begin{array}{l}\text { Defined as the porosity of the reservoir that reflects } \\
\text { the potential volume available for Hydrogen } \\
\text { storage. }\end{array}$ & $\begin{array}{l}\text { (Deveci, 2018; Deveci et al., 2015; } \\
\text { Hsu et al., 2012; Lewandowska- } \\
\text { Śmierzchalska et al., 2018) }\end{array}$ \\
\hline & $\begin{array}{l}\text { Storage } \\
\text { capacity }\end{array}$ & $\begin{array}{l}\text { Defined as the total capacity required for Hydrogen } \\
\text { storage reservoir. }\end{array}$ & $\begin{array}{l}\text { Deveci, 2018; Deveci et al., 2015; Hsu } \\
\text { et al., 2012; Llamas and Cámara, 2014; } \\
\text { Lord et al., 2014; Reitenbach et al., } \\
2015\end{array}$ \\
\hline \multirow{5}{*}{ Economics } & Labour & $\begin{array}{l}\text { Describes the costs attributed to the human } \\
\text { resources required for the operation of Hydrogen } \\
\text { storage facilities. }\end{array}$ & Deveci et al., 2015 \\
\hline & $\begin{array}{l}\text { Proximity to } \\
\text { suppliers \& } \\
\text { resources }\end{array}$ & $\begin{array}{l}\text { Defined as the distance to roads, power line, and } \\
\text { accessibility of raw materials. }\end{array}$ & Deveci et al., 2015 \\
\hline & $\begin{array}{l}\text { Infrastructure } \\
\text { availability }\end{array}$ & $\begin{array}{l}\text { Defined as the technological availabilities in terms } \\
\text { of basic infrastructures in the area. }\end{array}$ & Deveci et al., 2015 \\
\hline & Storage cost & $\begin{array}{l}\text { Defined as the total costs of Hydrogen storage in } \\
\text { terms of capturing, transportation, injection, and } \\
\text { storage. }\end{array}$ & $\begin{array}{l}\text { Deveci, 2018; Hsu et al., 2012; Deveci } \\
\text { et al., } 2015\end{array}$ \\
\hline & $\begin{array}{l}\text { Initial } \\
\text { investment }\end{array}$ & $\begin{array}{l}\text { The initial investment required to construct an } \\
\text { underground Hydrogen storage facility. }\end{array}$ & Deveci, 2018; Deveci et al., 2015 \\
\hline \multirow{2}{*}{$\begin{array}{l}\text { Health, Safety } \\
\text { and } \\
\text { Environment } \\
\text { (HSE) }\end{array}$} & Regional risks & $\begin{array}{l}\text { Describes the potential risks in the region regarding } \\
\text { the occurrence of natural disasters such as } \\
\text { earthquakes. }\end{array}$ & $\begin{array}{l}\text { Deveci, 2018; Deveci et al., 2015; } \\
\text { Llamas and Cámara, } 2014\end{array}$ \\
\hline & $\begin{array}{l}\text { Legal } \\
\text { restrictions }\end{array}$ & $\begin{array}{l}\text { Defined as the applicable environmental legislation } \\
\text { such as the required distance to protected areas, as } \\
\text { well as the applicable occupational health and } \\
\text { safety legislation. }\end{array}$ & $\begin{array}{l}\text { Deveci et al., 2015; Llamas and } \\
\text { Cámara, } 2014\end{array}$ \\
\hline \multirow{3}{*}{ Social } & $\begin{array}{l}\text { Social } \\
\text { acceptance }\end{array}$ & $\begin{array}{l}\text { Describes the overall perception of the local } \\
\text { communities for the construction of a Hydrogen } \\
\text { storage facility. }\end{array}$ & Deveci et al., 2015 \\
\hline & Job creation & $\begin{array}{l}\text { Defined as the new job opportunities created by the } \\
\text { construction and implementation of the facility. }\end{array}$ & Jahanshahi et al., 2019 \\
\hline & Local culture & $\begin{array}{l}\text { Describes the local culture properties that may need } \\
\text { special protection. }\end{array}$ & Llamas and Cámara, 2014 \\
\hline
\end{tabular}

The key issues addressed in the previous studies regarding the technical aspects of sustainability in underground gas storage are categorized as follows: capacity of storage (Hsu et al., 2012; Ramírez et al., 2010; Reitenbach et al., 2015; Simon et al., 2015), geological structure (such as depth, area, thickness, and 
tightness) (Hsu et al., 2012; LewandowskaŚmierzchalska et al., 2018), and reservoir porosity and permeability (Chadwick et al., 2008; Deveci, 2018). The economic aspect, which can be considered in the site selection of underground gas storage, has impressively been considered in several studies performed by some researchers (Deveci et al., 2015; Simon et al., 2015; Tarkowski and Czapowski, 2018). Lord et al. (2014) addressed the costs associated with the development and application of $\mathrm{H}_{2}$ storage facilities and stressed that the current limiting factor for widespread adoption of Hydrogen storage is the lack of economically feasible infrastructures. Moreover, as asserted by Tarkowski and Czapowski (2018), the costs of building underground reservoirs are much lower than the costs of building traditional reservoirs with the same capacity on the ground. The most frequent parameters associated with the economic aspects of sustainability, which have been addressed in underground gas storage studies, are various, such as labour cost (Deveci et al., 2015), initial investments (Simon et al., 2015), and the availability of basic infrastructure (Deveci et al., 2015). Table 1 reveals the most important parameters mentioned in the literature for the site selection of $\mathrm{H}_{2}$ underground facilities.

The social aspects of sustainability have recently gained some attention in some of the studies on the topic of gas underground storage. However, compared to the technical, HSE and economic criteria, the social aspect has been considered to have less importance (Atanda, 2019; Mapar et al., 2017). As defined by Mani et al. (2014), "social criteria of sustainability are considered as a human code of conduct which needs to be achieved in an equitable, inclusive and prudent manner". The recent studies have already addressed various social aspects while considering potential gas underground storage, including areas under cultural protection (Llamas and Cámara, 2014), social acceptability (Chadwick et al., 2008; Deveci et al., 2015) and the ability of this practice to create new jobs (Jahanshahi et al., 2019). Jahanshahi et al. (2019) pointed out that the capability of creating new jobs can also be considered as a social factor with an enormous impact on the development of energy facilities. Llamas and Cámara (2014) also proposed a new approach to solve the problems related to the selection of gas storage sites by considering the social criteria. However, it was asserted that the social aspects of sustainability, namely the social acceptance of the implementation are interlinked with the economic aspects and should be considered in an integrated approach along with other gas underground storage issues. On the other hand, as a new approach of sustainability, health, safety and environmental (HSE) aspects are seen as parallel challenges of sustainable development (Mapar et al., 2017). Sustainability approaches will be more robust when integrated with the HSE aspects (Mapar et al., 2017). These merged aspects have recently acquired adequate dominance at occupational level (Cunningham et al., 2010; IPIECA et al., 2015; Koskela, 2014). Some studies in the field of underground gas storage indicated that there are interlinking associations between environmental legislation and work health and safety (Deveci et al., 2015). Hsu et al. (2012) investigated the criteria of selection of the most appropriate gas storage locations and stated that, while deciding the best gas storage reservoir, regional risks are needed to be taken into account as one of the main affecting criteria. Ramírez et al. (2010) also explained that risk factors associated with underground gas storage also influence the suitability of a reservoir and asserted that it is important to take risk aspects into account as it will result in more realistic valuations of total gas storage potential. Also, according to Damen et al. (2006) risk assessment is a first step in a strategy-forming process to set-up management and control measures to minimise the risks of underground gas storage.

Table 1 represents the 18 most robust criteria extracted from the literature review for the site selection of the underground Hydrogen storage.

\section{METHODOLOGY}

\subsection{Fuzzi-Delphi methodology}

Delphi methodology is a useful tool employed to identify and prioritize criteria in a group, and in particular, questionnaires that are conducted to collect expert opinions (Kamali et al., 2019). This method is very popular among researchers in various fields (Okoli and Pawlowski, 2004). In the case of this method, respondents are selected based on their level of expertise and their skills in the field chosen to be analysed. In our study, the analysis regarding the site selection of the underground $\mathrm{H}_{2}$ storage was performed by using expert opinions in the field to rank the specific criteria. The expert panel was selected carefully, consisting of academic and non-academic experts with adequate knowledge in the field (Chang et al., 2000; Doyon et al., 1971; Kamali et al., 2019; Yousuf, 2007) combined with other 15 specialists, researchers and experts. There are a number of reports in the literature that argue for the effective application of the FuzzyDelphi methodology to make sustainability relevant decisions in various scientific fields (Hsu et al., 2010; Sánchez-Lezama et al., 2014; Tahriri et al., 2014).

In this study, a professional questionnaire was developed based on 18 identified criteria (see Table 1 ). Moreover, Fuzzy-Delphi approach was applied to categorize the criteria and sub-criteria along with their impact on Hydrogen site selection and rank them from 


\section{A Sustainable Approach for Site Selection of Underground Hydrogen Storage Facilities Using Fuzzy-Delphi Methodology \\ Journal Settlements and Spatial Planning, Special Issue, no. 6 (2020) 5-16 \\ Multi-Criteria Spatial Decision Support Systems for Sustainable Development}

the least to the most significant. Fuzzy numbers were defined as a set of numbers representing fuzzy space in the real $\mathrm{R}$ number, often used to explain unknown information in the decision-making process and for reaching conclusions (Ban and Coroianu, 2012).

Based on the selected approach, each fuzzy number in triangular form has been represented by three numbers as the following: $A=\left(a_{1}, a_{2}, a_{3}\right)$.

Membership functions that could interpret this profile were in accordance with the following equations (Gani and Assarudeen, 2012):

$$
y=m(x)=\left\{\begin{array}{lr}
0 & x<a_{1} \\
\frac{x-a_{1}}{a_{2}-a_{1}} a_{1} \leq x \leq a_{2} \\
\frac{a_{3}-x}{a_{3}-a_{2}} a_{2} \leq x \leq a_{3} \\
0 & x>a_{3}
\end{array}\right\}
$$

According to Table 2, in order to develop the questionnaire, a fuzzy scale, containing seven linguistic variables, and the respective triangular fuzzy numbers were used. The numeral mean (Eq. 2) (Hsu et al., 2010) was used to compute the fuzzy gravity of criteria, where $\mathrm{L}, \mathrm{M}$, and $\mathrm{U}$ expressed the fuzzy number ingredients. Eq. (3) was also used to defuzzy the values. Moreover, all criteria were defuzzied using Eq. (1) and defuzzied numbers were used to rank the criteria.

$$
L_{j}=\operatorname{Min}_{i}\left\{L_{i j}\right\}, M_{j}=\frac{1}{n} \sum_{i=1}^{n} M_{i j}, U_{j}=\operatorname{Max}_{i}\left\{U_{i j}\right\}
$$

$d f=\frac{1}{4}(L+2 M+U)$

Table 2. Linguistic variables and the relevant fuzzy scales used to rank the criteria for the site selection of $\mathrm{H}_{2}$ underground storage.

\begin{tabular}{l|rr}
$\begin{array}{c}\text { Linguistic } \\
\text { variable }\end{array}$ & $\begin{array}{c}\text { Fuzzy Scale } \\
(\mathbf{L}, \mathbf{M}, \mathbf{U})\end{array}$ & $d f=\frac{1}{4}(L+2 M+U)$ \\
\hline Extremely High & $(0.9,1.0,1.0)$ & 0.975 \\
Very High & $(0.7,0.9,1.0)$ & 0.875 \\
High & $(0.5,0.7,0.9)$ & 0.7 \\
Fair & $(0.3,0.5,0.7)$ & 0.5 \\
Low & $(0.1,0.3,0.5)$ & 0.3 \\
Very Low & $(0.0,0.1,0.3)$ & 0.125 \\
Extremely Low & $(0.0,0.0,0.1)$ & 0.025
\end{tabular}

The panel members were asked to specify the importance of each proposed sub-criterion based on the fuzzy scale revealed in Table 2.

After the revision and extraction of results from the first round, the average outputs were sent to the panel of experts and after reaching a consensus in the second round, results were interpreted to represent the most important sub-criteria for selecting the most suitable sites for the implementation of the underground Hydrogen storage facilities.

\subsection{Analysis of the results}

SPSS v.2.0.o was used for the data analysis. It should be taken into account that the numbers, which were input into the program, were defuzzied based on output responses. The outputs were analysed using the descriptive-analytic method. Cronbach's alpha was used to check and analyse the internal consistency of the answers provided by experts. The method employed is one of the methods of joints calculating internal consistency (reliability) which is generally used to evaluate the reliability of the time scale of questions (Béland et al., 2016). In this method, responses are examined and, finally, the coefficient is given to the answers. This coefficient has to be between 0 and 1 . If the coefficient value is closer to 1 , it means that the response is more reliable (Gottems et al., 2018). If the Cronbach's alpha coefficient is greater than 0.7 , it means that the questionnaire can be accounted to be reliable for further analysis (Pinto et al., 2014). The Kolmogorov-Smirnov (KS) test was also used to examine and analyse the non-matching responses and to check whether parameters were parametric (Zhang and Chen, 2018). In the present paper, so as to examine the responses more precisely, Shapiro-Wilk test was used to check whether data were normal (it should be noted that the sample size was less than 2000).

\section{RESULTS AND DISCUSSION}

Table 3 represents the importance of each subcriteria (shown as $d f$ column) extracted from the second-round questionnaire by applying the fuzzy scales (see also Table 2). The applied questionnaire utilized in this study can be found in the "Supplementary Information" section.

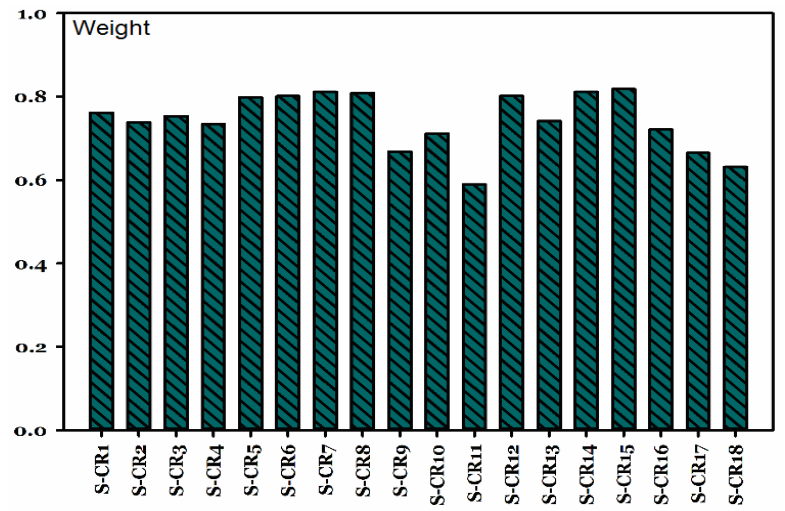

Fig. 3. Calculated weights of the sub-criteria for the site selection of underground Hydrogen storage.

Cronbach's alpha test was used to analyse the responses and the analysis was completed by using SPSS software. Finally, the obtained coefficient was 0.767. Since this value was greater than 0.7 , the responses were consistent and reliable (Table 4). 
Behrouz NEMATI, Mahsa MAPAR, Peyman DAVARAZAR, Sara ZANDI, Mahsa DAVARAZAR,

Dina JAHANIANFARD, Mehdi MOHAMMADI

Journal of Settlements and Spatial Planning, Special Issue, no. 6 (2020) 5-16

Multi-Criteria Spatial Decision Support Systems for Sustainable Development

The Kolmogorov-Smirnov and Shapiro-Wilk tests were used for parametric analysis and nonparametric analysis for output responses. Given that all outputs were less than 0.05 , the responses were nonnormalized and non-parametric.

Table 3. Linguistic variables and the relevant fuzzy scales employed to rank the criteria used for the site selection of $\mathrm{H}_{2}$ underground storage.

\begin{tabular}{|c|c|c|c|c|}
\hline Criteria & & Sub-Criteria & $\begin{array}{c}\text { Fuzzy Scale } \\
(\mathrm{L}, \mathrm{M}, \mathrm{U})\end{array}$ & $\mathrm{d} f$ \\
\hline \multirow{8}{*}{ Technical } & S-CR1 & Geology & $(0.3,0.873,1.0)$ & 0.7617 \\
\hline & S-CR2 & Depth & $(0.3,0.827,1.0)$ & 0.7383 \\
\hline & S-CR3 & Area & $(0.3,0.857,1.0)$ & 0.7536 \\
\hline & S-CR4 & Thickness & $(0.3,0.820,1.0)$ & 0.7350 \\
\hline & S-CR5 & Caprock thickness & $(0.3,0.847,1.0)$ & 0.7983 \\
\hline & S-CR6 & Caprock permeability & $(0.3,0.853,1.0)$ & 0.8017 \\
\hline & S-CR7 & Reservoir permeability and porosity & $(0.3,0.873,1.0)$ & 0.8117 \\
\hline & S-CR8 & Storage capacity & $(0.3,0.867,1.0)$ & 0.8083 \\
\hline \multirow{5}{*}{ Economics } & S-CR9 & Labour & $(0.3,0.687,1.0)$ & 0.6683 \\
\hline & S-CR10 & Proximity to suppliers \& resources & $(0.3,0.773,1.0)$ & 0.7117 \\
\hline & S-CR11 & Infrastructure availability & $(0.3,0.680,1.0)$ & 0.5900 \\
\hline & S-CR12 & Storage cost & $(0.3,0.853,1.0)$ & 0.8017 \\
\hline & S-CR13 & Initial investment & $(0.3,0.833,1.0)$ & 0.7417 \\
\hline \multirow{2}{*}{$\begin{array}{l}\text { Health, safety and } \\
\text { environment (HSE) }\end{array}$} & S-CR14 & Regional risks & $(0.3,0.873,1.0)$ & 0.8117 \\
\hline & S-CR15 & Legal restrictions & $(0.3,0.887,1.0)$ & 0.8183 \\
\hline \multirow{3}{*}{ Social } & S-CR16 & Social acceptance & $(0.3,0.793,1.0)$ & 0.7217 \\
\hline & S-CR17 & Job creation & $(0.3,0.680,1.0)$ & 0.6650 \\
\hline & S-CR18 & Local culture & $(0.3,0.713,1.0)$ & 0.6317 \\
\hline
\end{tabular}

Table 4. Results of Case Processing Summary (SPSS 25.0 software) for the analysis of the site selection for $\mathrm{H}_{2}$ underground storage.

\begin{tabular}{|r|l|r|r|r|r|}
\hline \multicolumn{2}{|c|}{ Analysis } & N & $(\%)$ & \multicolumn{1}{|c|}{ No. of items } & Cronbach's Alpha \\
\hline \multirow{3}{*}{ Cases } & Valid & 18 & 100 & 15 & \\
\cline { 2 - 7 } & Excluded & 0 & 0 & 0 & \\
\cline { 2 - 7 } & Total & 18 & 100 & 15 & 0.767 \\
\hline
\end{tabular}

Table 5. Results of the normality test performed on the data gained from the responses based on the criteria and sub-criteria for the site selection of $\mathrm{H}_{2}$ underground storage.

\begin{tabular}{|c|c|c|c|c|c|c|}
\hline \multirow{2}{*}{ Criteria } & \multicolumn{3}{|c|}{ Kolmogorov-Smirnov } & \multicolumn{3}{|c|}{ Shapiro-Wilk } \\
\hline & Statistic & df & Sig. & Statistic & df & Sig. \\
\hline S-CR1 & 0.448 & 15 & 0.000 & 0.615 & 15 & 0.000 \\
\hline S-CR2 & 0.369 & 15 & 0.000 & 0.773 & 15 & 0.002 \\
\hline S-CR3 & 0.414 & 15 & 0.000 & 0.707 & 15 & 0.000 \\
\hline S-CR4 & 0.303 & 15 & 0.001 & 0.847 & 15 & 0.016 \\
\hline S-CR5 & 0.339 & 15 & 0.000 & 0.776 & 15 & 0.002 \\
\hline S-CR6 & 0.306 & 15 & 0.001 & 0.794 & 15 & 0.003 \\
\hline S-CR7 & 0.308 & 15 & 0.000 & 0.795 & 15 & 0.003 \\
\hline S-CR8 & 0.338 & 15 & 0.000 & 0.786 & 15 & 0.002 \\
\hline S-CR9 & 0.435 & 15 & 0.000 & 0.627 & 15 & 0.000 \\
\hline S-CR10 & 0.298 & 15 & 0.001 & 0.838 & 15 & 0.012 \\
\hline S-CR11 & 0.281 & 15 & 0.002 & 0.865 & 15 & 0.028 \\
\hline S-CR12 & 0.269 & 15 & 0.005 & 0.770 & 15 & 0.002 \\
\hline S-CR13 & 0.254 & 15 & 0.010 & 0.858 & 15 & 0.022 \\
\hline S-CR14 & 0.308 & 15 & 0.000 & 0.795 & 15 & 0.003 \\
\hline S-CR15 & 0.334 & 15 & 0.000 & 0.782 & 15 & 0.002 \\
\hline S-CR16 & 0.269 & 15 & 0.005 & 0.864 & 15 & 0.028 \\
\hline S-CR17 & 0.302 & 15 & 0.001 & 0.806 & 15 & 0.004 \\
\hline S-CR18 & 0.288 & 15 & 0.002 & 0.828 & 15 & 0.009 \\
\hline
\end{tabular}

In the previous step, it was found that our responses were non-parametric. Regarding the nonparametricity of the answers, it was necessary to analyze the uniformity in the perception of respondents to the questionnaire. Kruskal-Wallis test was used in this regard. In this test, the output number should be greater than 0.05 , so that the respondents' perception of the criteria is the same. The calculated test coefficient 


\section{A Sustainable Approach for Site Selection of Underground Hydrogen Storage Facilities Using Fuzzy-Delphi Methodology

was determined to be 0.055. This coefficient represented that all respondents had a similar understanding of the questionnaire. This test was used to compare the mean of two or more groups of samples. The hypotheses of this test were based on statistical comparison of the existence or non-existence of differences between groups and based on responses. If the program output for this test was less than 0.05, there would be a difference between the respondents' perception regarding the questions and criteria (Maimaiti et al., 2019).

Table 6. Kruskal-Wallis Test (SPSS 25.0 software) performed on the gained results from the responses to the questionnaire for the site selection of $\mathrm{H}_{2}$ underground storage.

\begin{tabular}{|l|r|}
\hline \multicolumn{1}{|c|}{ Test Statistics } & \multicolumn{1}{|c|}{ Answer } \\
\hline Kruskal-Wallis H & 23.329 \\
\hline df & 14 \\
\hline Asymp. Sig. & 0.055 \\
\hline
\end{tabular}

Table 7 and Fig. 4 demonstrate the final ranking of the sub-criteria at the overall scale.

Table 7. Final ranking of the sub-criteria for the site selection of underground Hydrogen storage.

\begin{tabular}{|c|c|c|c|}
\hline Criteria & Sub-Criteria & $\begin{array}{l}\text { Criteria } \\
\text { Ranking }\end{array}$ & $d f=\frac{1}{4}(L+2 M+U)$ \\
\hline HSE & $\begin{array}{l}\text { Legal } \\
\text { restrictions }\end{array}$ & 1 & 0.8183 \\
\hline Technical & $\begin{array}{l}\text { Reservoir } \\
\text { permeability } \\
\text { and porosity }\end{array}$ & \multirow[t]{2}{*}{2} & \multirow[t]{2}{*}{0.8117} \\
\hline HSE & Regional risks & & \\
\hline Technical & $\begin{array}{l}\text { Storage } \\
\text { capacity }\end{array}$ & 3 & 0.8083 \\
\hline Technical & $\begin{array}{l}\text { Caprock } \\
\text { permeability }\end{array}$ & \multirow[t]{2}{*}{4} & \multirow[t]{2}{*}{0.8017} \\
\hline Economic & Storage cost & & \\
\hline Technical & $\begin{array}{l}\text { Caprock } \\
\text { thickness }\end{array}$ & 5 & 0.7983 \\
\hline Technical & Geology & 6 & 0.7617 \\
\hline Technical & Area & 7 & 0.7536 \\
\hline Economic & $\begin{array}{l}\text { Initial } \\
\text { investment }\end{array}$ & 8 & 0.7417 \\
\hline Technical & Depth & 9 & 0.7383 \\
\hline Technical & Thickness & 10 & 0.7350 \\
\hline Social & $\begin{array}{l}\text { Social } \\
\text { acceptance }\end{array}$ & 11 & 0.7217 \\
\hline Economic & $\begin{array}{ll}\text { Proximity } & \text { to } \\
\text { suppliers } & \& \\
\text { resources } & \end{array}$ & 12 & 0.7117 \\
\hline Economic & Labour & 13 & 0.6683 \\
\hline Social & Job creation & 14 & 0.6650 \\
\hline Social & Local culture & 15 & 0.6317 \\
\hline Economic & $\begin{array}{l}\text { Infrastructure } \\
\text { availability }\end{array}$ & 16 & 0.5900 \\
\hline
\end{tabular}

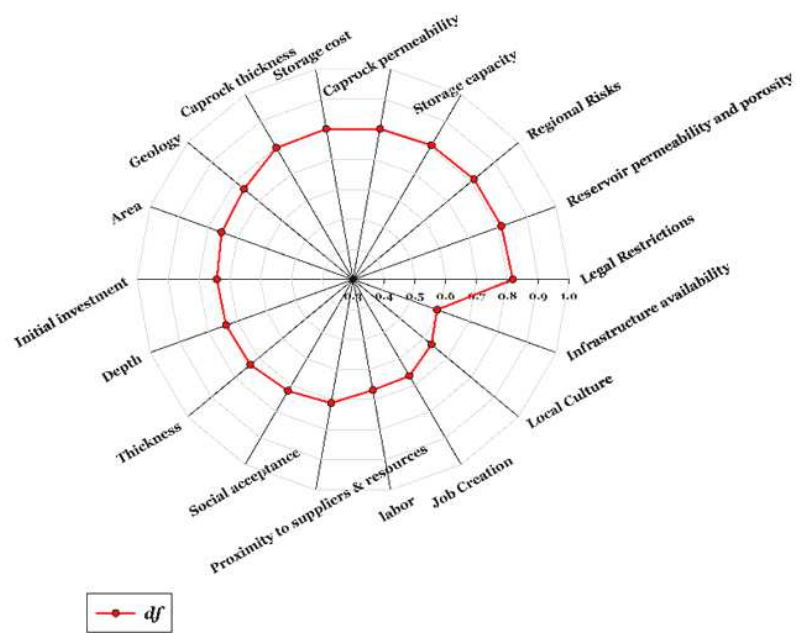

Fig. 4. Final ranking of the sub-criteria for the site selection of Hydrogen underground storage.

Regarding Figure 4, the vector of de-fuzzy ranks based on the Fuzzy-Delphi calculations showed that "legal restrictions" (S-CR15), with a decisive advantage over the others (df: 0.8183 ), appeared as the most important sub-criteria while selecting the $\mathrm{H}_{2}$ underground storage site. In addition, "reservoir permeability and porosity", "regional risks", and "storage capacity" were ranked next in importance among the studied parameters (see also Table 7). It is noticeable in Table 1 and Figure 4 that both sub-criteria associated with HSE criterion were classified in the top three ranks, demonstrating the panel of experts to be heavily in favour of the HSE criteria and considered them among the most important aspects of sustainability in the site selection of $\mathrm{H}_{2}$ underground storage. This might be due to the direct impact of HSE issues on the target groups whose life could be affected by the $\mathrm{H}_{2}$ underground storage sites directly, for instance because of the potential risks of occurrence of disasters, namely earthquakes or natural fires. These findings were in line with the criteria suggested in the international standard ISO 37120 related to indicators for city services and quality of life (ISO, 2014), indicating emergency issues and fire protection as some of the most essential services to meet the responsibility of the involved parties to protect the life and well-being of their target groups in compliance with the sustainability goals (Mapar et al., 2017). These findings could be also compared with the objectives of Deveci et al. (2015) who demonstrated the importance of the risk of explosion in the underground gas storage to be significant, and that it could be considered as an independent and key category besides the technical, economic and social criteria. This study could be accounted to be successful to highlight the role of HSE aspects of sustainability.

Moreover, most sub-criteria located in the middle level of Table 1 (see ranks 5 to 10) belonged to 
"Technical aspects", which demonstrated that the technical issue of sustainability regarding the $\mathrm{H}_{2}$ underground storage was ranked second in comparison with other HSE, social and economic aspects, while playing an important role in the site selection of $\mathrm{H}_{2}$ underground storage. These findings were partially in line with the study of Chadwick et al. (2008), who analysed the underground gas storage in the Mid Norway and illustrated that a proper technical investigation was deemed to be helpful to rationalize these issues. Therefore, it was clear that the HSE and the technical issues of sustainability for the site selection of $\mathrm{H}_{2}$ underground storage were more underscored, since all the HSE sub-criteria gained the first and second ranks of the total, whereas, most of the technical sub-criteria were allocated ranks of 5 to 10 (the middle level), while the social and economic criteria were positioned on the lowest ranks (between 11 and 16) (Table 3). On the other hand, the social subcriteria (see Fig. 4 and Table 1) were placed at the lowest levels along with the economic sub-criteria (ranks 11 to 16).

Although the social sub-criteria were ranked the lowest, it is of high importance to notice that this study was successful in involving the social aspects of sustainability in the underground gas storage, since, overall, the panel were in favour of the role of social sub-criteria in the site selection and its related subcriteria in the study. The findings of the present study could also be compared with the gaps indicated in the second sections of this study. Regarding the results presented in the studies of Atanda (2019) and Mapar et al. (2017), in which the attention to the social aspects of sustainability in different fields of studies was found to be lower in comparison with the economic issues, our findings showed that, the social and economic aspects of sustainability on the $\mathrm{H}_{2}$ underground storage were ranked approximately the same.

The findings of this study also attempted to resolve the concern of Etxteberria et al. (2015) over the exclusion of social issues from the sustainability criteria set in most studies. The findings emphasized a more explicit criterion to reflect the "social" aspect of sustainability in setting up the most suitable locations for underground gas storage. However, more in-depth studies are needed to more extensively approach different aspects of social sustainability when deciding on the location of underground gas storage.

Regarding the economic sub-criteria, it was obvious that the storage costs (ranked $4^{\text {th }}$ ) and initial investment (ranked $8^{\text {th }}$ ) gained much more attention than the "proximity to suppliers \& resources", "labour" and "infrastructure availability" (ranked 12, 13 and 16). We could conclude that to gain much more success on continuous improvement of the underground gas storage site selection, the initial investment costs should be investigated by more in-depth analyses, before and beyond other cost-benefit analyses of the $\mathrm{H}_{2}$ underground storage program. As mentioned above, we noted that the implementation of underground $\mathrm{H}_{2}$ storage has not yet been commercialized. Thus, the achieved results can be applied to facilitate the investigation in regards with notifying the area in which more investments are required.

Consequently, the involved parties such as governments, relevant stakeholders, and researches with the proper insight can be more encouraged to apply and utilize the $\mathrm{H}_{2}$ underground storage in large scales. In addition, underground $\mathrm{H}_{2}$ storages seem to be an appropriate choice due to the large amount of investments required for building the over ground storages for $\mathrm{H}_{2}$ and the requirements of tanks for the sequestration; and, the results obtained regarding the proper locations for the commercial implementation of such storages can be easily sought by using methodologies such as GIS-fuzzy methods (KhavarianGarmsir and Rezaei, 2015).

Moreover, the obtained results gained from this study can be applied as a model in order to predict the destiny of such storages and prevent the occurrence of undesirable hazardous events. Also, one of main reasons negatively affecting the implementation of the underground gas storages is the lack of relevant standards for building, adjustments, and the use of these facilities (IEA Greenhouse Gas R\&D Programme, 2003; Reitenbach et al., 2015). These results can also be utilized for the formation of the respective regulations and standards.

\section{CONCLUSIONS}

This study was performed to identify the most important criteria and sub-criteria involved in the selection of the most suitable sites for the establishment of underground Hydrogen facilities.

A Fuzzy-Delphi methodology was employed to prioritize the identified criteria and sub-criteria. According to the results achieved, legal restrictions were identified as the most important criterion. Reservoir permeability and porosity and regional risks were also identified as the next priorities. HSE and technical criteria were also considered as the most important and main criteria.

The results can clearly demonstrate that the governmental approach can considerably affect the selection of the most suitable sites for the establishment of the Hydrogen underground storage facilities. Also, there are some technical barriers such as lack of standards and regulations for building, adjustments, and utilizations of such facilities, which should be overcome to promote their commercial implementation. 


\section{A Sustainable Approach for Site Selection of Underground Hydrogen Storage Facilities Using Fuzzy-Delphi Methodology \\ Journal Settlements and Spatial Planning, Special Issue, no. 6 (2020) 5-16 \\ Multi-Criteria Spatial Decision Support Systems for Sustainable Development}

\section{REFERENCES}

Aliev R. A., Aliev R.R., Ahmedov I. Z., Aliyeva K.R. (2004), Fuzzy Delphi Method. Knowledge 1, 3-4. Education Society of Azerbaijan Republic.

Amos W. A. (1998), Costs of Storing and Transporting Hydrogen. National Renewable Energy Laboratory. Retrieved from: https://www.nrel.gov/docs/fy99osti /25106.pdf

Atanda J. O. (2019), Developing a Social Sustainability Assessment Framework. Sustainable Cities and Society 44, 237-52. DOI: https://doi.org/ 10.1016/j.scs.2018.09.023

Babonneau F., Haurie A., Vielle M. (2016), Assessment of balanced burden-sharing in the $2050 \mathrm{EU}$ climate/energy roadmap: A metamodeling approach. Climatic Change 134(4), 505-19. DOI: 10.1007/s10584015-1540-x

Ban A. I., Coroianu L. (2012), Nearest Interval, Triangular and Trapezoidal Approximation of a Fuzzy Number Preserving Ambiguity. International Journal of Approximate Reasoning 53, 805-36. DOI: https://doi.org/10.1016/j.ijar.2012.02.001

Béland S., Pichette F., Jolani S. (2016), Impact on Cronbach's Alpha of Simple Treatment Methods for Missing Data. The Quantitative Methods for Psychology 12(1), 57-73. DOI: 10.20982/tqmp.12.1.p057

Bouzon M., Govindan K., Taboada Rodriguez C. M., Campos L. M. S. (2016), Identification and analysis of reverse logistics barriers using fuzzy Delphi method and AHP. Resources, Conservation and Recycling 108, 182-197. DOI: https://doi.org/10.1016/ j.resconrec.2015.05.021

Chadwick A., Arts R., Bernstone C., May F., Thibeau S., Zweigel P. (2008), Best Practice for the Storage of $\mathrm{CO} 2$ in Saline Aquifers Observations and Guidelines from the Sacs And CO2 Store Projects. Retrieved from: https://core.ac.uk/download/pdf/ 63085.pdf

Chang P. T., Huang L. C., Lin H. J. (2000), The fuzzy Delphi method via fuzzy statistics and membership function fitting and an application to the human resources. Fuzzy Sets and Systems 112, 511-520. DOI: https://doi.org/10.1016/So165-0114(98)00067-O

Crotogino F., Donadei S., Bünger U., Landinger H. (2010), Large-Scale Hydrogen Underground Storage for Securing Future Energy Supplies. In: Detlef Stolten, Thomas Grube (Eds.): 18th World Hydrogen Energy Conference 2010 - WHEC 2010 Parallel Sessions Book 4: Storage Systems / Policy Perspectives, Initiatives and Co-operations. Proceedings of the WHEC, May 16.-21. 2010, Essen (January 2010), 27-45. Retrieved from: https://core.ac.uk/download/pdf/34994534.pdf

Cunningham, T. R., Galloway-Williams N., Geller S. E. (2010), Protecting the planet and its people: How do interventions to promote environmental sustainability and occupational safety and health overlap? Journal of Safety Research 41(5), 407-416. DOI: https://doi.org/10.1016/j.jsr.2010.08. 002 Damen K., Faaij A., Turkenburg W. C. (2006), Health, Safety and Environmental Risks of Underground Co2 Storage - Overview of Mechanisms and Current Knowledge. Climatic Change 74, 288-318. DOI: 10.1007/s10584-005-0425-9

Deveci M. (2018), Site selection for hydrogen underground storage using interval type-2 hesitant fuzzy sets. International Journal of Hydrogen Energy 43(19), 9353-9368. DOI: https://doi.org/10.1016/j. ijhydene.2018.03.127

Deveci M., Demirel N. Ç., John R., Özcan E. (2015), Fuzzy Multi-Criteria Decision Making for Carbon Dioxide Geological Storage in Turkey. Journal of Natural Gas Science and Engineering 27, 692-705. DOI: https://doi.org/10.1016/j.jngse.2015.09.004

Doyon L. R., Sheehan T. V., Zagor H. I. (1971), Classroom Exercises in Applying the Delphi Method for Decision-Making. Socio-Economic Planning Sciences 5(4), 363-375. DOI: https://doi.org/10.1016/o0380121(71)90022-X

European Commission (2011), Communication of the European Commission to the European Parliament, the Council, the European Economic and Social Committee and the Committee of the Regions. Energy Roadmap 2050, COM(2011) 885 Final. 15 December 2011, Brussels. Retrieved from: https://eurlex.europa.eu/LexUriServ/LexUriServ.do?uri=COM:20 11:0885:FIN:EN:PDF

Evans D. J., Reay D. M., Riley N. J., Mitchell W. I., Busby J. (2006), Appraisal of underground energy storage potential in Northern Ireland. Nottingham, UK, British Geological Survey. DOI: http://nora.nerc.ac.uk /id/eprint/7398

Etxeberria A. I., Garayar A., Calvo Sánchez J. A. (2015), Development of Sustainability Reports for Farming Operations in the Basque Country Using the Delphi Method. Revista de Contabilidad 18(1), 44-54. DOI: https://doi.org/10.1016/j.rcsar.2014.03.004.

Gani N. A., Assarudeen M. S. N. (2012), A New Operation on Triangular Fuzzy Number for Solving Fuzzy Linear Programming Problem. Applied Mathematical Sciences 6, 525-532. Retrieved from: https://www.researchgate.net/publication/265583357

Gottems L. B. D., Carvalho E. M. P., Guilhem D., Pires M. R. G. M. (2018), Good practices in normal childbirth: reliability analysis of an instrument by Cronbach's Alpha. Revista Latino-Americana de Enfermagem, 26, e300o. DOI: https://dx.doi.org/10. $1590 / 1518-8345.2234 .3000$

Hagemann B., Ganzer L., Panfilov M. (2018), Field Scale Modeling Of Bio-Reactions during Underground Hydrogen Storage. ECMOR XVI - 16th European Conference on the Mathematics of Oil Recovery. DOI: 10.3997/2214-4609.201802116 
Hopper M. (2017), Grid-Scale Hydrogen Energy Storage: A Techno-Economic Cost-Benefit Analysis for Sweden. Master of Science Thesis. KTH School of Industrial Engineering and Management. Stockholm. Retrieved from: http://www.diva-portal.se/smash/get /diva2:1197531/FULLTEXTo1.pdf

Hsu C. W., Chen L. T., Hu A. H., Chang Y. M. (2012), Site selection for carbon dioxide geological storage using analytic network process. Separation and Purification Technology 94, 146-153. DOI: https://doi. org/10.1016/j.seppur.2011.08.019

Hsu Y. L., Lee c. H., Kreng V. B. (2010), The Application of Fuzzy Delphi Method and Fuzzy AHP in Lubricant Regenerative Technology Selection. Expert Systems with Applications 37(1), 419-425. DOI: https: //doi.org/10.1016/j.eswa.2009.05.068

Hsueh S. L. (2015), Assessing the Effectiveness of Community-Promoted Environmental Protection Policy by Using a Delphi-Fuzzy Method: A Case Study on Solar Power and Plain Afforestation in Taiwan. Renewable and Sustainable Energy Reviews 49, 1286-1295. DOI: https://doi.org/10.1016/j.rser.2015.05.008

HYUNDER (2014), Assessment of the Potential, the Actors and Relevant Business Cases for Large Scale and Long Term Storage of Renewable Electricity by Hydrogen Underground Storage in Europe. Deliverable No. 6.2a Representative Case Studies with a focus on salt cavern storage. Case Study Germany. Executive Summary. Retrieved from: http://www.lbst.de/ download/2014/Report_HyUnder_German_Case_Stu dy_D6_2_a_2014-02-17_ES_final.pdf

IEA Greenhouse Gas R\&D Programme (2003), Barriers to Overcome in Implementation of $\mathrm{CO}_{2}$ Capture and Storage (2): Rules and Standards for the Transmission and Storage of $\mathrm{CO}_{2}$. Report Number $\mathrm{PH}_{4} / 23$. Retrieved from: https://ieaghg.org/docs/ General_Docs/Reports/ Barriers\%202\%20\%20Rules\%20and\%20standards\%20fo r\%2otrans\%2oand\%2ostorage.pdf

IPIECA, API, IOGP (2015), Oil and gas industry guidance on voluntary sustainability reporting. Retrieved from: http://www.ipieca.org/media/2849/ og_industry_guidance_on_voluntary_sustainability_r eportnig_3rd_ed_2016.pdf

ISO (2014), ISO 37120 - Sustainable Development of Communities: Indicators for City Services and Quality of Life. International Organization for Standardization. Retrieved from: https://www.iso.org/obp/ui/ \#iso:std:iso:37120:ed-2:v1:en

Jahanshahi A., Kamali M., Khalaj M., Khodaparast Z. (2019), Delphi-based prioritization of economic criteria for development of wave and tidal energy technologies. Energy 167, 819-827. DOI: https://doi.org/10.1016/j.energy.2018.11.040

Kádár P. (2014), Pros and Cons of the Renewable Energy Application. Acta Polytechnica Hungarica 11(4),
211-224. Retrieved from: https://www.uni-obuda.hu /journal/Kadar_50.pdf

Kamali, M., Alesheikh A. A., Khodaparast Z., Hosseinniakani S. M., Alavi Borazjani S. A. (2015), Application of Delphi-AHP and Fuzzy-GIS Approaches for Site Selection of Large Extractive Industrial Units in Iran. Journal of Settlements and Spatial Planning 6(1), 9-17. Retrieved from: http://geografie.ubbcluj.ro/ccau/jssp/arhiva_1_2015/ 02JSSP012015.pdf

Kamali M., Alesheikh A. A., Alavi Borazjani S. A., Jahanshahi A., Khodaparast Z., Khalaj M. (2017), Delphi-AHP and Weighted Index Overlay-GIS Approaches for Industrial Site Delphi-AHP and Weighted Index Overlay-GIS Approaches for Industrial Site Selection Case Study: Large Extractive Industrial Units in Iran. DOI: 10.24193/JSSP.2017.2.03

Kamali M., Costa M. E., Aminabhavi T. M., Capela I. (2019), Sustainability of treatment technologies for industrial biowastes effluents. Chemical Engineering Journal 370, 1511-1521. DOI: https://doi.org/10.1016/j.cej.2019.04.010

Kamali M., Persson K. M., Costa M. E., Capela I. (2019), Sustainability criteria for assessing nanotechnology applicability in industrial wastewater treatment: Current status and future outlook. Environment International 125, 261-76. DOI: https:// doi. org/ 10.1016/j.envint.2019.01.055

Khavarian-Garmsir A. R., Rezaei M. R. (2015), Selection of Appropriate Locations for Industrial Areas Using GIS-Fuzzy Methods. A Case Study of Yazd Township, Iran. Journal of Settlements and Spatial Planning 6(1), 19-25. Retrieved from: http://geografie.ubbcluj.ro/ccau/jssp/arhiva_1_2015/ 03JSSP012015.pdf

Koskela, M. (2014), Occupational health and safety in corporate social responsibility reports. Safety Science 68, 294-308. DOI: https://doi.org/10.1016/j.ssci. 2014.04.011 Larsen H, Feidenhans'l R., Sønderberg Petersen L. (2004), Risø energy report 3. Hydrogen and its competitors. Roskilde: Risø National Laboratory. Denmark. Forskningscenter Risoe. Risoe-R, No. 1469(EN). Retrieved from: https://backend. orbit.dtu. $\mathrm{dk} /$ ws/portalfiles/portal/7711411/ris_r_1469.pdf

Lewandowska-Śmierzchalska J., Tarkowski R., Uliasz-Misiak B. (2018), Screening and ranking framework for underground hydrogen storage site selection in Poland. International Journal of Hydrogen Energy 43(9), 4401-4414. DOI: https://doi.org/10.1016 /j.ijhydene.2018.01.089

Llamas B., Cámara A. (2014), Application of multicriteria algorithm to select suitable areas for storing CO2: CO2SiteAssess Software. Energy Procedia 63, 4977-4986. DOI: https://doi.org/10.1016/j.egypro. 2014.11.527 


\section{A Sustainable Approach for Site Selection of Underground Hydrogen Storage Facilities Using Fuzzy-Delphi Methodology \\ Journal Settlements and Spatial Planning, Special Issue, no. 6 (2020) 5-16 \\ Multi-Criteria Spatial Decision Support Systems for Sustainable Development}

Lord A. S., Kobos P. H., Borns D. J. (2014), Geologic storage of hydrogen: Scaling up to meet city transportation demands. International Journal of Hydrogen Energy 39(28), 15570-15582. DOI: http://dx.doi.org/10.1016/j.ijhydene.2014.07.121

Maimaiti P, Feng Sen L., Aisilahong G., Maimaiti R., Yun W. Y. (2019), Statistical analysis with Kruskal Wallis test for patients with joint contracture. Future Generation Computer Systems 92, 419-423. DOI: https://doi.org/10.1016/j.future.2018. 10.024

Mani V., Agrawal R., Sharma V. (2014), Supplier Selection Using Social Sustainability: AHP Based Approach in India. International Strategic Management Review 2(2), 98-112. DOI: https://doi.org/10.1016 /j.ism.2014.10.003

Mapar M., Jafari M. J., Mansouri N., Arjmandi R., Azizinejad R., Ramos T. B. (2017), Sustainability Indicators for Municipalities of Megacities: Integrating Health, Safety and Environmental Performance. Ecological Indicators 83, 271-291. DOI: https://doi.org/10.1016/j.ecolind.2017. 08.012

Okoli C., Pawlowski S. D. (2004), The Delphi Method as a Research Tool: An Example, Design Considerations and Applications. Information and Management 42(1), 15-29. DOI: https://doi.org/ 10.1016/j.im.2003.11.002

Pesonen O., Alakunnas T. (2017), Energy Storage. A Missing Piece of the Puzzle for the Self-Sufficient Living. DOI: http://urn.fi/URN:ISBN:978-952-316186-3

Pinto F. S. T., Fogliatto F. S., Qannari E. M. (2014), A method for panelists' consistency assessment in sensory evaluations based on the Cronbach' $\mathrm{s}$ alpha coefficient. Food Quality and Preference 32(A), 41-47. DOI: 10.1016/j.foodqual.2013.06.006

Pritchard D. K, Rattigan W. M. (2010), Hazards of Liquid Hydrogen: Position Paper. Health and Safety Laboratory. Retrieved from: https://www.hse.gov.uk/ research/rrpdf/rr769.pdf

Ramírez A., Hagedoorn S., Kramers L., Wildenborg T., Hendriks C. (2010), Screening CO2 storage options in The Netherlands. International Journal of Greenhouse Gas Control 4(2), 367-380. DOI: https://doi.org/10.1016/j.ijggc.2009.10.015

Read S., Lindhult E., Mashayekhi A. (2016), The Inefficiencies of Energy Efficiency: Reviewing the Strategic Role of Energy Efficiency and Its Effectiveness in Alleviating Climate Change. Journal of Settlements and Spatial Planning, Spec. Iss. 5, 77-87. DOI: 10.19188/o8JSSPSI052016

Reitenbach V., Ganzer L., Albrecht D., Hagemann B. (2015), Influence of Added Hydrogen on Underground Gas Storage: A Review of Key Issues.
Environmental Earth Sciences 73(11), 6927-6937. DOI: 10.1007/s12665-015-4176-2

Reuß M., Grube T., Robinius M., Preuster P., Wasserscheid P., Stolten D. (2017), Seasonal storage and alternative carriers: A flexible hydrogen supply chain model. Applied Energy 200, 290-302. DOI: https://doi.org/10.1016/j.apenergy.2017.05.050

Roumpedakis T., Vlavakis P., Braimakis K., Grimekis D., Karellas S. (2018), Hydrogen Production and Storage. In book: Renewable Energy Engineering: Solar, Wind, Biomass, Hydrogen and Geothermal Energy Systems, 272-323. DOI: 10.2174/9781681087191118030008.

Rocco, R. (2016), Policy Frameworks for Energy Transition in England: Challenges in a Former Industrial City. Journal of Settlements and Spatial Planning, Spec. Iss. 5, 41-52. DOI: https://doi.org/ 10.19188/05jsspsio52016

Sainz-Garcia, A., Abarca E., Rubi V., Grandia F. (2017), Assessment of feasible strategies for seasonal underground hydrogen storage in a saline aquifer. International Journal of Hydrogen Energy 42(26), 16657-16666. DOI: http://dx.doi.org/10.1016/j. ijhydene.2017.05.076

Sánchez-Lezama A. P., Cavazos-Arroyo J., Albavera-Hernández C. (2014), Applying the Fuzzy Delphi Method for determining socio-ecological factors that influence adherence to mammography screening in rural areas of Mexico, Cadernos de Saúde Pública 30(2), 245-58. DOI: http://dx.doi.org/10.1590/o102311 Xoo025113

Sherif, S. A., Barbir F., Nejat Veziroglu T. (2003), Principles of Hydrogen Energy Production, Storage and Utilization. Journal of Scientific and Industrial Research 62(1), 46-63. DOI: 10.1016/s01406701(04)91346-x

Simon, J., Ferriz A. M., Correas L. C. (2015), HyUnder - Hydrogen Underground Storage at Large Scale: Case Study Spain. Energy Procedia 73, 136-144. DOI: http://dx.doi.org/10.1016/j.egypro.2015.07.661

Tahriri F., Mousavi M., Hozhabri Haghighi S., Dawal S. Z. (2014), The Application of Fuzzy Delphi and Fuzzy Inference System in Supplier Ranking and Selection. Journal of Industrial Engineering International 10. DOI: https://doi.org/10.1007/ s40092-014-0066-6

Tarkowski R., Czapowski G. (2018), Salt domes in Poland - Potential sites for hydrogen storage in caverns. International Journal of Hydrogen Energy, 21414-21427. DOI: https://doi.org/10.1016/j.ijhydene .2018.09.212.

Türkseven Doğrusoy İ., Serin E. (2015), A Holistic Approach of Energy Efficient Building Design. Case Study: A Housing Design Proposal in Seferihisar, İzmir, Turkey. Journal of Settlements and Spatial Planning 6(1), 37-49. Retrieved from: http://geografie.ubbcluj.ro /ccau/jssp/arhiva_1_2015/o5JSSP012015.pdf 
Tzimas E., Filiou C., Peteves S. D., Veyret J.-B. (2003), Hydrogen Storage: State-of-the-Art and Future Perspective. European Communities. Retrieved from: https://publications.jrc.ec.europa.eu/repository/bitstre am/JRC26493/EUR\%2020995\%20EN.pdf

Yousuf M. I. (2007), Using Experts' Opinions through Delphi Technique - Practical Assessment, Research and
Evaluation. Practical Assessment, Research \& Evaluation 12(4), 1-8. Retrieved from: http://pareonline.net/getvn.asp? $v=12 \& n=4$.

Zhang B., Chen R. (2018), Nonlinear Time Series Clustering Based on Kolmogorov-Smirnov 2D Statistic. Journal of Classification 35(3), 394-421. DOI: 10.1007/soo357-018-9271-0

\section{SUPPLEMENTARY MATERIAL}

The questionnaire conducted in this research to rank the criteria for the site selection of the underground Hydrogen storage is revealed below.

\begin{tabular}{|c|c|c|c|c|c|c|c|c|}
\hline $\begin{array}{c}\text { Main } \\
\text { criteria }\end{array}$ & Sub-criteria & $\begin{array}{l}\text { Extremely } \\
\text { low }\end{array}$ & $\begin{array}{l}\text { Very } \\
\text { low }\end{array}$ & Low & Fair & High & Very high & $\begin{array}{l}\text { Extremely } \\
\text { high }\end{array}$ \\
\hline \multirow{7}{*}{ 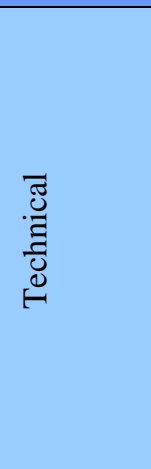 } & Geology & $\square$ & $\square$ & $\square$ & $\square$ & $\square$ & $\square$ & $\square$ \\
\hline & Depth & $\square$ & $\square$ & $\square$ & $\square$ & $\square$ & $\square$ & $\square$ \\
\hline & Area & $\square$ & $\square$ & $\square$ & $\square$ & $\square$ & $\square$ & $\square$ \\
\hline & Thickness & $\square$ & $\square$ & $\square$ & $\square$ & $\square$ & $\square$ & $\square$ \\
\hline & Caprock thickness & $\square$ & $\square$ & $\square$ & $\square$ & $\square$ & $\square$ & $\square$ \\
\hline & $\begin{array}{l}\text { Reservoir permeability } \\
\text { and porosity }\end{array}$ & $\square$ & $\square$ & $\square$ & $\square$ & $\square$ & $\square$ & $\square$ \\
\hline & Storage capacity & $\square$ & $\square$ & $\square$ & $\square$ & $\square$ & $\square$ & $\square$ \\
\hline \multirow{5}{*}{ 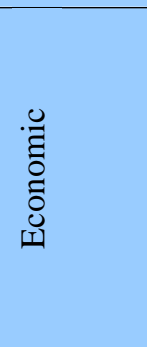 } & Labour & $\square$ & $\square$ & $\square$ & $\square$ & $\square$ & $\square$ & $\square$ \\
\hline & $\begin{array}{l}\text { Proximity to suppliers } \\
\text { \&resources }\end{array}$ & $\square$ & $\square$ & $\square$ & $\square$ & $\square$ & $\square$ & $\square$ \\
\hline & Infrastructure availability & $\square$ & $\square$ & $\square$ & $\square$ & $\square$ & $\square$ & $\square$ \\
\hline & Storage costs & $\square$ & $\square$ & $\square$ & $\square$ & $\square$ & $\square$ & $\square$ \\
\hline & Initial investment & $\square$ & $\square$ & $\square$ & $\square$ & $\square$ & $\square$ & $\square$ \\
\hline \multirow{2}{*}{ 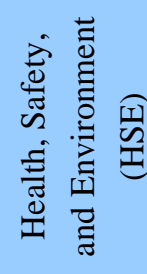 } & Regional risks & $\square$ & $\square$ & $\square$ & $\square$ & $\square$ & $\square$ & $\square$ \\
\hline & Legal restrictions & $\square$ & $\square$ & $\square$ & $\square$ & $\square$ & $\square$ & $\square$ \\
\hline \multirow{3}{*}{$\begin{array}{l}\bar{\pi} \\
\frac{\pi}{0} \\
0\end{array}$} & Social acceptance & $\square$ & $\square$ & $\square$ & $\square$ & $\square$ & $\square$ & $\square$ \\
\hline & Job creation & $\square$ & $\square$ & $\square$ & $\square$ & $\square$ & $\square$ & $\square$ \\
\hline & Local culture & $\square$ & $\square$ & $\square$ & $\square$ & $\square$ & $\square$ & $\square$ \\
\hline
\end{tabular}

